\title{
Pelatihan Perawatan Sepeda Motor PGM FI (Programmed Fuel Injection) bagi Siswa SMKN 1 Kec. Luak Kab. 50 Kota
}

\author{
Nuzul Hidayat*) 1, M. Yasep Setiawan ${ }^{1}$, Ahmad Arif ${ }^{2}$, Wanda Afnison ${ }^{1}$, Irma Yulia Basri ${ }^{1}$ \\ ${ }^{1}$ Pendidikan Teknik Otomotif, Fakultas Teknik Otomotif, Universitas Negeri Padang \\ *) Corresponding author, $\equiv$ nuzulhidayat.ft.unp.ac.id
}

(Di isi oleh editor) Revisi 23/06/2019; Diterima 26/07/2019; Publish 08/08/2019

\section{Kata kunci:}

pelatihan, siswa, sepeda motor

\section{Abstrak}

Perkembangan teknologi tersebut telah mencakup di segala bidang aspek kehidupan masyarakat. Ilmu Pengetahuan dan Teknologi (IPTEK) merupakan salah satu perkembangan yang sangat pesat, di mana era ini membawa iklim yang semakin terbuka untuk saling bekerja sama dan saling melengkapi.

Masalah yang paling menonjol adalah praktek pada mata pelajaran Teknik Sepeda Motor, selain kekurangan dalam alat dan bahan praktek juga dihadapkan dengan kondisi alat dan bahan praktek yang sudah using (out of date) dari sisi teknologi, akibatnya siswa ketika lulus ilmu mereka jauh ketinggalan dengan yang dibutuhkan dunia kerja.

Dari kendala yang dialami oleh siswa SMKN 1 SMKN 1 Luak Kab. Lima Puluh Kota maka TIM PKM Jurusan teknik Otomotif Universitas Negeri Padang, melihat ada peluang untuk melakukan pengabdian untuk membantu memberikan solusi dengan permasalahan yang ada yakninya memeberikan pelatihan tentang Pelatihan Perawatan Sepeda Motor PGM FI (Programmed Fuel Injection), kegiatan yang di tawarkan adalah memberikan keterbaruan ilmu bagi siswa dalam menyelesaikan praktek dengan menggunakan tipe kendaraan sepeda motor yang sudah berbasis teknologi full elektronik secara komputerisasi.

Metode pendekatan yang digunakan ada dua yaitu dengan metode classroom dan practice. Dimana kegiatan akan dilakukan secara tatap muka dengan beberapa kali pertemuan dan untuk tindak lanjut akan dilakukan dengan pembimbingan. Kedepannya akan di tunjuk beberapa guru yang sudah cukup mampu dan cakap dalam melakukan pembimbingan. 


\section{Suluah Bendang: Jurnal Ilmiah Pengabdian Kepada Masyarakat}

Vol.19, No.3, 2019

Nuzul Hidayat 1, M. Yasep Setiawan 2, Ahmad Arif 3, dkk

This is an open access article distributed under the Creative Commons Attribution License, which permits unrestricted use,

distribution, and reproduction in any medium, provided the original work is properly cited. (C2019 by author (s)

\section{(c) (1) PENDAHULUAN}

\section{Analisis Situasi}

Perkembangan teknologi saat ini telah berkembang pesat, dimana perkembangannya sangat bermanfaat yang tidak terhingga bagi kehidupan manusia. Perkembangan teknologi tersebut telah mencakup di segala bidang aspek kehidupan siswa. Ilmu Pengetahuan dan Teknologi (IPTEK) merupakan salah satu perkembangan yang sangat pesat, di mana era ini membawa iklim yang semakin terbuka untuk saling bekerja sama dan saling melengkapi. Di sisi lain, era ini juga membawa persaingan yang sangat kompetitif.

Seiring dengan perkembangan teknologi tersebut dibutuhkan penigkatan kualitas Sumber Daya Manusia (SDM) yang handal. Pendidikan merupakan salah satu bidang yang bertujuan untuk membentuk manusia seutuhnya yang handal dan berkompeten di segala bidang. Sekolah merupakan salah satu pendidikan formal yang akan menghasilkan lulusan yang nantinya akan dibutuhkan baik di dunia usaha/dunia industri. Sekolah yang mampu menghasilkan Sumber Daya Manusia (SDM) yang terampil dan berkualitas lebih yang ditujukan kepada SMK (Sekolah Menengah Kejuruan). Hal ini dilatar belakangi oleh Peraturan Pemerintah (PP) No. 29 Tahun 1990, Pasal 3 ayat 2, yaitu, "Menyiapkan peserta didik untuk memasuki lapangan kerja serta mengembangkan sikap professional"[1].

Hal ini merupakan tantangan bagi SMK (Sekolah Menengah Kejuruan). Yang disesuaikan dengan adanya Kurikulum Tingkat Satuan Pendidikan (KTSP) SMK (2006), SMK memiliki tujuan untuk: 1) Menyiapkan peserta didik agar menjadi manusia produktif, mampu bekerja mandiri, mengisi lowongan pekerjaan yang ada di dunia usaha dan dunia industry sebagai tenaga kerja tingkat menengah sesuai dengan kompetisi dalam program keahlian yang dipilihnya, 2) Menyiapkan peserta didik agar mampu memilih karir, ulet dan gigih dalam berkompetensi, beradaptasi di lingkungan kerja, dan mengembangkan sikap professional dalam bidang keahlian dany diminatinya, 3) Membekali peserta didik dengan ilmu pengetahuan, teknologi dan seni, agar mampu mengembangkan diri di kemudian hari baik secara mandiri maupun melalui jenjang pendidikan yang lebih tinggi, 4) Membekali peserta didik dengan kompetensi-kompetensi yang sesuai dengan program keahlian yang dipilihnya[2].

Menurut [3] tentang sistem pendidikan nasional disebut bahwa tujuan pendidikan sekolah menengah kejuruan (SMK) adalah mempersiapkan peserta didik terutama bekerja dalam bidang tertentu. Selanjutnya secara spesifik tujuan SMK program Teknik sepeda motor menurut kurikulum 2009 adalah:

a. Memasuki lapangan kerja serta mengembangkan sikap profesional dalam bidang sepeda motor

b. Mampu memilih karir, mampu berkompetensi dan mampu mengembangkan diri dalam bidang sepeda motor

c. Menjadi tenaga kerja tingkat menengah untuk mengisi kebutuhan dunia usaha dan industri, pada saat ini maupun masa yang akan datang.

d. Menjadi warga negara yang produktif, aktif, adaptif dan kreatif. 
Berdasarkan data [4] Tingkat pengangguran terbuka (TPT) di Indonesia pada Februari 2017 mengalami penurunan menjadi 5,33\% dari Februari 2016 yang sebesar 5,50\%. Dari 131,55 juta orang yang masuk sebagai angkatan kerja, terdapat 124,54 juta orang yang bekerja, dan sisanya 7,01 juta orang dipastikan pengangguran. Dari jumlah tersebut, pengangguran yang berasal dari jenjang Sekolah Menengah Kejuruan (SMK) menduduki peringkat teratas sebesar 9,27\% yang disusul oleh pengangguran lulusan Sekolah Menengah Atas (SMA) sebesar 7,03\%. Sedangkan, dari jenjang Sekolah Menengah Pertama (SMP) sebesar 5,36\%, Diploma III (D3) sebesar 6,35\%, dan universitas 4,98\% (http://detikfinance.com). Selanjutnya, menurut Badan Pusat Statistik (BPS) bahwa per-November 2017, sebanyak 128,06 juta penduduk Indonesia adalah angkatan kerja, jumlahnya bertambah 2,62 juta orang dari Agustus 2016 (http://bps.com). Sejalan dengan itu, Tingkat Partisipasi Angkatan Kerja (TPAK) juga meningkat 0,33 poin. Dalam setahun terakhir, pengangguran bertambah 10 ribu orang, sementara TPT turun sebesar 0,11 poin. Dilihat dari tingkat pendidikan, TPT untuk Sekolah Menengah Kejuruan (SMK) paling tinggi diantara tingkat pendidikan lain, yaitu sebesar 11,41 persen.

Pada 2030-2040, Indonesia diprediksi akan mengalami bonus demografi, yaitu penduduk dengan usia produktif lebih banyak dibandingkan dengan penduduk non produktif. Di masa ini juga diprediksi penduduk usia produktif mencapai 64\% dari total penduduk Indonesia yang diperkirakan mencapai 297 juta jiwa. Oleh sebab itu, banyaknya penduduk dengan usia produktif harus diikuti oleh peningkatan kualitas, baik dari sisi pendidikan, keterampilan, dan semakin ketatnya persaingan di pasar tenaga kerja. Selanjutnya, berdasarkan [5] menyatakan bahwa arah kebijakan pembangunan pendidikan nasional fokus pada peningkatan akses pendidikan menengah yang wajib diselaraskan dengan akselerasi peningkatan mutu pendidikan. Pendidikan menengah tidak hanya mencetak lulusan SMU yang akan melanjutkan ke Perguruan Tinggi namun juga mempersiapkan lulusan SMK yang memiliki keterampilan memadai untuk menjadi tenaga kerja siap pakai dan terampil.

Namun, masih ada SMK yang belum bisa mewujudkannya rencana pemerintah,. Ini terlihat dari beberapa SMK terutama yang swasta di Sumatera Barat yang belum relevan antara kompetensi lulusan dengan kebutuhan DU/DI, sehingga pada saat mereka lulus, mereka tidak siap bekerja, dan perusahaan yang menerima mereka juga keberatan. Penyelarasan kompetensi lulusan SMK terhadap kebutuhan DU/DI tidak terlepas dari sumber daya yang ada di sekolah. SMK negeri dan sudah mapan serta sudah lama berdiri, dari segi pengadaan beberapa unit sepeda motor dengan teknologi terbaru beserta peralatan servisnya bisa mereka lakukan. Akan tetapi berbeda terlihat dengan SMK swasta yang inputnya dari siswa berlatar belakang ekonomi menengah ke bawah, masih memiliki sarana dan prasarana yang belum memadai karena keterbatasan dana sekolah. Kondisi seperti ini terjadi di salah satu SMK Teknologi dan Rekayasa di Kab. 50 Kota, yaitu SMKN 1 Kec. Luak Kab. 50 Kota terutama pada Program Studi Teknik Sepeda Motor Jurusan Teknik Otomotif.

Kompetensi yang sangat dituntut dalam pengembangan pengetahuan siswa diantaranya adalah kemapuan afektif, kognitif dan psikomotorik. Pada sisi psikomotorik adalah berhubungan dengan kemapuan melakukan suatu pekerjaan dengan baik dan benar secara SOP. Mustahil siswa dapat melakukan pekerjaan dengan baik dan benar tanpa alat dan bahan. Hal yang paling menonjol adalah tentang system bahan bahar pada kendaraan terutama kendaraan bermotor yang sangat pesat. Perkembangan system bahan bakar dengan system karburator sudah digantikan dengan sistem komputerisasi yang lebih dikenal dengan programed fuel injection. Teknologi ini dikenal dengan PGM FI yang mana diagnosa kerusakan dilakukan secara komputerisasi dan scan tool yang membuituhkan pengalaman dan pengetahuan dalam mengoperasikannya. Di SMK pada umumnya belum memiliki scan tool tersebut dan kalau pun ada belum mampu untuk mengoperasikannya secara optimal. Dalam hal ini peran perguruan 


\title{
Suluah Bendang: Jurnal Ilmiah Pengabdian Kepada Masyarakat
}

Vol. 19, No.3, 2019

\author{
Nuzul Hidayat 1, M. Yasep Setiawan 2, Ahmad Arif 3, dkk
}

tinggi sangat penting karena menjadi stakeholder dari SMK memberikan pengatahuan dan penyegaran serta keterbaharuan ilmu kepada siswa SMK.

SMKN 1 Kec. Luak Kab. 50 Kota sebagai sebuah lembaga pendidikan untuk tingkat menengah kejuruan, yang memiliki tujuan yaitu menyiapkan siswa untuk memasuki lapangan karja yang memilki kompetensi dan dapat mengembangkan diri secara profesionalisme serta meneruskan pendidikan ke jenjang yang lebih tinggi. Demi terwujudnya tujuan tersebut, sekolah membangun visi yaitu menjadi pusat pelayananpindidikan dan pelatihan kejuruan yang berstandar nasional/ internasional. Upaya SMKN 1 Kec. Luak Kab. 50 Kota untuk mewujudkan visi tersebut adalah menyiapkan SDM yang terampil, kreatif dan berwawasan luas dalam bidang keahliannya dan senantiasa berorientasi mutu dalam setiap kegiatannya. Selain itu juga dikembangkan iklim belajar dan bekerja secara kreatif, tulus dengan pemberdayaan potensi sekolah meliputi guru, siswa dan siswa dengan landasan moral adalah kejujuran dan kedisplinan.

Oleh karena itu, maka lulusan SMK harus dipersiapkan memiliki kompetensi yang dibutuhkan oleh dunia usaha/ dunia industri (DU/DI) sehingga dapat menekan tingkat pengangguran lulusan SMK. Salah satu kompetensi yang menjadi kebutuhan oleh DU/DI pada bidang teknik otomotif adalah pengetahuan dan keterampilan teknologi sepeda motor. Berdasarkan permasalahan tersebut melalui Program Kemitraan Siswa (PKM) maka pihak kampus UNP berkeinginan untuk melakukan pelatihan kepada siswa SMK dengan judul " Pelatihan Perawatan Sepeda Motor PGM FI (Programmed Fuel Injection) bagi Siswa SMKN 1 Luak Kab. 50 Kota". Dengan Pelatihan ini diharapkan dapat membantu pemerintah dalam rangka meningkatkan kompetensi calon lulusan SMKN 1 Kec. Luak Kab. 50 Kota dengan mengadakan pelatihan kompetensi teknologi sepeda motor. SMK yang terpilih sebagai mitra dalam kegiatan ini adalah SMKN 1 Kec. Luak Kab. 50 Kota.Memuat latar belakang masalah, kesenjangan antara kenyataan dan ideal dan tujuan.

\section{Solusi dan Target}

Dalam pembahasan ini maka beberapa solusi yang akan ditawarkan yang kongkret real time dan memiliki sustainability dari Program Kemitraan Siswa (PKM) ini. Dalam penyelesaian masalah yang terjadi dilapangan ada beberapa tahapan yang akan dilakukan diantaranya:

\section{a. Tahapan obervasi (observation periode)}

Dalam tahapan ini tim inti PKM akan melakukan obervasi secara mendalam dan rinci tentang akar permasalahan yang terjadi pada siswa dalam peningkatan kompetensi lulusan di SMKN 1 Kec. Luak Kab. 50 Kota, terutama pada pemahan sistem bahan bakar pada sepeda motor yang menggunakan teknologi Programed Fuel injection (PGM FI). Tim ini akan membuat list atau daftar masalah yang dihadapi secara umum dan keseluruhan. Didalam kegiatan observasi ini tim PKM juga akan melakukan wawancara secara acak tentang pengetahuan siswa tentang pemahaman sistem bahan bakar Programed Fuel injection (PGM FI) pada sepeda motor dan penanganan kerusakannya..

\section{b. Tahapan analisis (analysis periode)}

Setelah didapatkan data tentang masalah kemudian akan dilihat skala priotitas (priority scale) permasalahn yang bagian mana yang membutuhkan penanganan secepatnya dan di komparasikan dengan kapasitas tim inti PKM dalam melakukan penyesaian masalah. Setelah di analisis dari beberapa segi baik segi kemampuan siswa mengenal sistem bahan bakar Programed Fuel injection (PGM FI) pada sepeda motor yang pernah mereka pahami, kemudian akan 
dilakukan metode pendekatan yang paling tepat dalam penyampaian informasi kepada siswa tersebut tentang sistem bahan bakar Programed Fuel injection (PGM FI) pada sepeda motor. Dalam teknik penyampaian materi akan dilakukan dengan 2 metoda yaitu secara teori (classroom) dan praktik ( practice), karena kedua metode ini dianggap sebagai teknik pendekatan yang paling tepat, alasannya setelah siswa mendapatkan teori tentang sistem bahan bakar Programed Fuel injection (PGM FI) kemudian mereka juga akan melakukan teknik perbaikan secara mandiri dan didamping oleh tim inti PKM dan tim Ahli dilapangan.

\section{c. Tahapan pelaksanaan (execute periode)}

Tahapan ini akan dilakukan pada saat kegiatan berlangsung yakninya selama kegiatan berlangsung dilokasi kegiatan. Sebelum melakukan materi maka akan dilakukan pretest untuk mengukur kemapuan dan pengetahuan siswa tentang sistem bahan bakar Programed Fuel injection (PGM FI) pada sepeda motor, dan hasilnya akan di rekap sehingga tim PKM mendapat pedoman kemana arah materi yang akan diberikan. Untuk kegitan teori dapat dilaksanakan di ruang kelas di SMKN 1 Kec. Luak Kab. 50 Kota kapasitas maksimal 20-25 orang, sedangkan untuk kegiatan praktik dapat dilakukan di workshop SMKN 1 Kec. Luak Kab. 50 Kota. Untuk peralatan yang bersifat mahal dan langka akan di lakukan peminjaman dari kampus sedangkan untuk bahan akan dilakukan pembelian sesuai dengan kebutuhan. Selama kegiatan akan dibimbing secara langsung oleh tim inti PKM dan dibantu dengan tim Ahli dan juga beberapa mahasiwa. Saat kegiatan berlangsung tim PKM ini akan memberikan pemahaman dan pengetahuan tentang sistem bahan bakar Programed Fuel injection (PGM FI) pada sepeda motor siswa dan siswa yang memiliki bakat dalam bidang motor bakar sehingga tim PKM akan memberikan pendalaman materi untuk di jadikan leader atau pioneer supaya bisa membagi ilmunya kepada teman-teman yang belum memahami secara sempurna.

\section{d. Tahapan purna kegiatan (finish periode)}

Dalam tahapan ini maka tim akan mengukur ketercapaian dari kegiatan dengan melakukan evaluasi posttest yang sudah di rencanakan, beberapa hal yang akan menjadi indikator keberhasilan adalah diantaranya,

1) Pemahaman siswa tentang sistem bahan bakar Programed Fuel injection (PGM FI) pada sepeda motor, baik dari sisi komponen cara kerja dan fungsi masing-masing komponen.

2) Siswa mengetahui kerusakan dengan mengenal signal yang diberikan oleh sepeda motor.

3) Siswa mampu mengunakan scan tools dengan baik dan benar dakam menganalisa kerusakan pada sepeda motor.

4) Siswa mampu menggunakan four gas analyzer dalam pengukuran kadar emisi gas buang.Memuat garis besar solusi permasalahan, rencana kegiatan pengabdian, waktu dan tempat pengabdian, prosedur kegiatan data dan target.

\section{METODE PELAKSANAAN}

\section{Tempat dan Waktu}

Kegiatan PKM di lakukan di workshop Teknik sepeda motor SMKN 1 Kec. Luak Kab. 50 Kota. Dalam kegiatan ini siswa di SMKN 1 Kec. Luak Kab. 50 Kota menyediakan tempat pelaksanaan yang didalamnya masuk pada fasilitas kegiatan seperti meja, kursi, sound system dan kebutuhan kegiatan dalam ruangan teori. Sedangkan peserta berpartisipasi mambawa sepeda motor dengan sistem bahan bakar Programed Fuel injection (PGM FI) pada sepeda motor dijadikan bahan praktek selain model mesin yang di bawa oleh Tim PKM. Kegiatan PKM dilaksanakan pada dari tanggal 8 - 11 Agustus 2019.

\section{Khalayak Sasaran}




\section{Suluah Bendang: Jurnal IImiah Pengabdian Kepada Masyarakat}

Vol.19, No.3, 2019

Nuzul Hidayat 1, M. Yasep Setiawan 2, Ahmad Arif 3, dkk

Dalam kegiatan PKM ini yang menjadi sasaran adalah siswa kelas XI jurusan Teknik Sepeda Motor yang sudah mempelajari sistem bahan bakar pada sepeda motor. Disamping itu juga melibatkan guru mata pelajaran bidang teknik sepeda motor.

\section{Metode Pengabdian}

Selama kegiatan berlangsung maka antara tim penyelenggara PKM dengan siswa sudah melakukan pembahasan pengantar atau pendahuluan. Dari pembahasan tersebut dijadikan sebagai landasan dan titik tolak dalam pelaksanaan kegiatan. Pendekatan yang akan dilakukan ada 2 cara yaitu secara teori dan praktek, dengan bobot masing-masing yaitu $30 \%$ teori dan $70 \%$ praktek, ini dilakukan karena menimbang kondisi dilapangan karena dalam kegiatan ini akan lebih banyak demontrasi dan praktek langsung pada kendaraan. Disamping itu penyampaian secara praktek lebih banyak porsinya akan mengurangi kebosanan saat penyampaian materi. Disamping itu juga materi yang dilakukan secara langsung dipraktekan maka siswa akan lebih cepat memahami kegiatan yang dilakukan karena mereka terlibat langsung dan mengetahui permasalahannya secara jelas.

Tahapan metode pendekatan penyampaian materi secara umum

a. Secara teori diantaranya

- Dengan mengunakan media power point yang didalamnya ada animasi cara kerja, gambar kerja serta video tentang perawatan sistem bahan bakar Programed Fuel injection (PGM FI) pada sepeda motor.

- Diskusi tentang sistem bahan bakar Programed Fuel injection (PGM FI) pada sepeda motor

b. Secara praktek diantaranya

- Pemahaman nama komponen dan fungsi sistem bahan bakar Programed Fuel injection (PGM FI) pada sepeda motor dengan bantuan simulator

- Pemahaman cara kerja sistem bahan bakar Programed Fuel injection (PGM FI) pada sepeda motor dengan mengunakan simulator
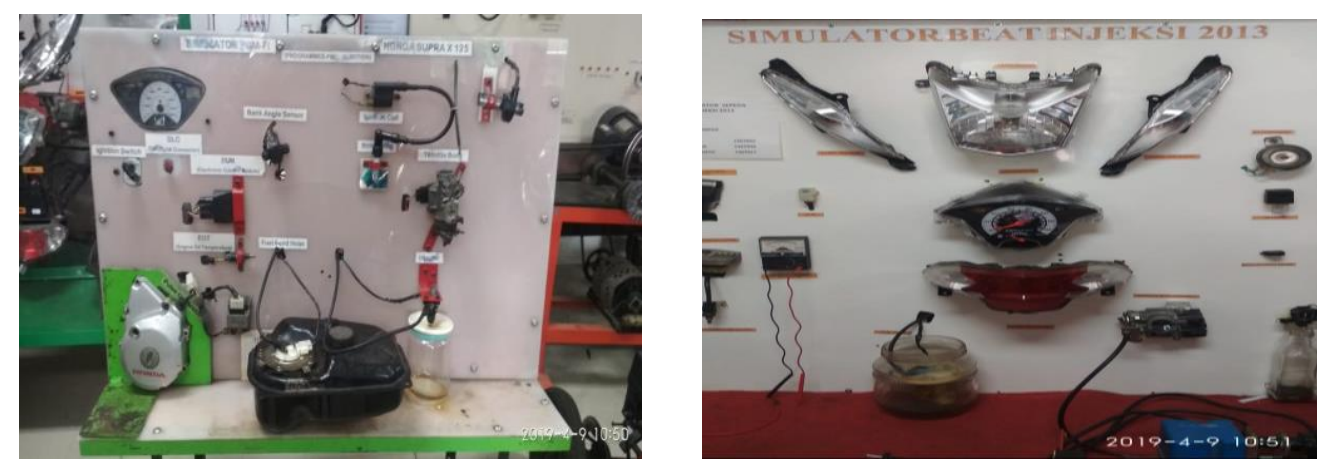

Gambar 1. Simulator sistem bahan bakar Programed Fuel injection (PGM FI) pada sepeda motor

Instrument yang akan digunakan diantaranya:

a. Iquteche HDIAG Honda (scan tools)

Diagnostic tool iquteche HDIAG untuk motor honda injeksi berfungsi seperti engine scanner bagi mesin injeksi, umtuk mendereksi error atau kerusakan di sistem injeksi motor, 
b. Tachometer

Kegunaan tachometer atau juga dikenal dengan RPM digunakan untuk mengukur putaran mesin khususnya jumlah putaran yang dilakukan oleh sebuah poros dalam satu satuan waktu dan biasanya dipakai pada peralatan kendaraan bermotor.

c. Four gas analyzer

Alat ini dipergunakan untuk menguji gas buang dari kendaraan bermotor (Mobil) berbahan bakar bensin, dengan keakurasian yang tinggi sehingga dapat mengurangi terjadinya polusi udara yang diakibatkan oleh gas buang kendaraan.

\section{Indikator Keberhasilan}

Secara keseluruhan hal uang diharapkan dari pengabdian ini adalah diantarannya:

1. Siswa mampu melakukan pemahaman tentang cara kerja sistem bahan bakar injeksi pada sepeda motor.

2. Siswa mampu mengetahui nama komponen dan fungsinya serta mengetahui lokasi penempatan pada sepeda motor.

3. Siswa mampu pemeriksaan kerusakan pada komponen sistem bahan bakar injeksi.

4. Siswa mampu melakukan penanganan kerusakan pada sistem bahan bakar injeksi.

5. Siswa mampu menggunakan alat scan tool untuk mendeteksi kerusakan dan memprogran ulang sistem injeksi pada motor.

\section{Metode Evaluasi}

Beberapa tahapan dalam pelaksanaan evaluasi yang akan dilakukan yaitu:

1. Tahapan pengukuran kemampuan dasar (pretest) tentang sistem bahan bakar Programed Fuel injection (PGM FI) pada sepeda motor.

2. Tahapan pengukuran kemampuan lajutan setelahdiberikan materi dan pemahaman tentang sistem bahan bakar Programed Fuel injection (PGM FI) pada sepeda motor (postest).

Setelah kegiatan dilakukan maka beberapa hal yang akan tetap dilakukan diantaranya:

a. Melakukan evaluasi program dengan menyebarkan angket kepada siswa dan pihak SMKN 1 Kec. Luak Kab. 50 Kota sehingga dari penialaian tersebut akan dapat diketahui ketercapaian kegiatan PKM tersebut.

b. Untuk keberlanjutan tim PKM akan melakukan koordinasi dengan siswa yang sudah dikader dan sekolah, sehingga siswa umum dapat berkonsultasi dengan tim yang dikader ini, jika permasalahannya tidak selesai maka tim PKM yang menangani secara langsung.

\section{HASIL DAN PEMBAHASAN}

Pada hari pertama kegiatan dilakukan pembukaan secara resmi oleh kepala sekolah SMKN 1 Luak Drs. Idil Wahadi M.Pd dan juga didampingi ketua program Jurusan Teknik otomotif serta beberapa guru bidang keahlian teknik otomotif. Kepala sekolah dan jajaran menyambut dengan baik kegiatan PKM ini karena kegiatan ini untuk pertama sekalinya dilakukan di SMKN 1 Luak selama sekolah itu didirikan. Sedangkan untuk kegiatan di ikuti oleh sebanyak 25 orang peserta yang berasal dari siswa kelas XI SMKN 1 Luak. 

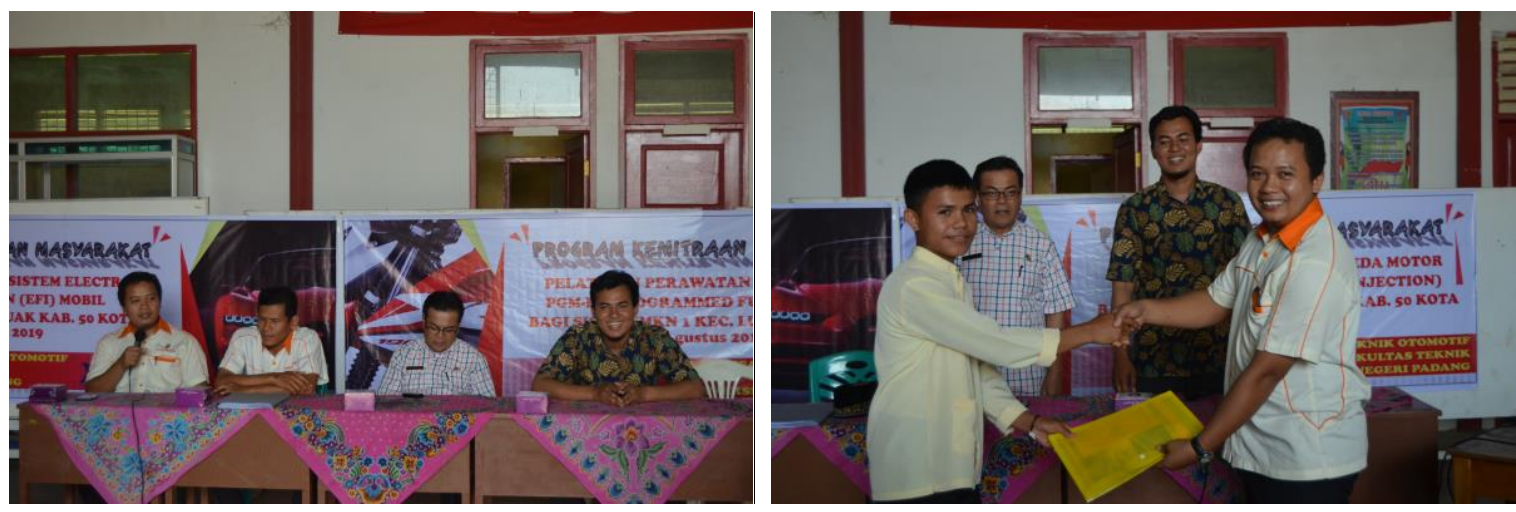

Gambar 2. Pembukaan kegiatan dan penyerahan seminar kit

Selama kegiatan berlangsung dilakukan proses pelatihan pada hari pertama secara teori yang dibimbing oleh instruktur yang sudah propfesional dibidang sistem bahan bakar injeksi pada sepeda motor dengan teknologi Programed Fuel injection (PGM FI). Tim instruktur yaitu Ahmad Arif, S.Pd MT yang akan membimbing materi tentang sensor dan tranduser, Wagino, S.Pd, M.Pdt membimbing bagian diagnosa kerusakan pada sistem Programed Fuel injection (PGM FI), Wanda Afnison S.Pd, MT akan membimbing pengujian emisi gas buang pada sepeda motor.

Tabel 1. Materi pelatihan yang diberikan

\begin{tabular}{|c|c|c|c|}
\hline $\begin{array}{l}\mathrm{N} \\
\mathbf{o}\end{array}$ & Materi Latihan & $\begin{array}{c}\text { Juml } \\
\text { ah } \\
\text { Jam }\end{array}$ & Instruktur \\
\hline 1 & $\begin{array}{l}\text { Pengenalan konsep dasar sistem bahan bakar } \\
\text { Programed Fuel injection (PGM FI) pada sepeda motor }\end{array}$ & 4 & Ahmad Arif, S.Pd MT \\
\hline 2 & $\begin{array}{l}\text { Pengenalan instrument yang digunakan dalam kegiatan } \\
\text { paraktek dan bagaiaman mengoperasikannya }\end{array}$ & 4 & Ahmad Arif, S.Pd MT \\
\hline 3 & Pengenalan komponen fungsi dan cara kerja & 4 & Ahmad Arif, S.Pd MT \\
\hline 4 & $\begin{array}{l}\text { Demonstrasi penjelasan cara kerja dari sistem bahan } \\
\text { bakar Programed Fuel injection (PGM FI) pada sepeda } \\
\text { motor dan simulator }\end{array}$ & 4 & Wagino, S.Pd, M.Pdt \\
\hline 5 & $\begin{array}{l}\text { Diagnosa kerusakan pada sistem bahan bakar } \\
\text { Programed Fuel injection (PGM FI) pada sepeda motor }\end{array}$ & 4 & Wagino, S.Pd, M.Pdt \\
\hline 6 & $\begin{array}{l}\text { Demontrasi perbaikan dari sistem bahan bakar } \\
\text { Programed Fuel injection (PGM FI) pada sepeda motor } \\
\text { setelah didiagnosa }\end{array}$ & 5 & Wanda Afnison S.Pd, MT \\
\hline 7 & $\begin{array}{l}\text { Melakukan diagnosa secara sendiri-sendiri atau } \\
\text { kelompok pada sepeda motor secara utuh }\end{array}$ & 5 & Wanda Afnison S.Pd, MT \\
\hline & Total Jam & 30 & \\
\hline
\end{tabular}


Kegitan PKM ini sebelum diberikan tim PKM melakukan pengukuran awal kemampuan siswa atau peserta pelatihan (pretest) berupa daftar pertanyaan yang berhubungan dengan sistem bahan bakat injeksi Programed Fuel injection (PGM FI) sebanyak 25 butir soal jenis objektif dan 5 butir soal essay. Dari nilai ini kita bisa mendapatkan acuan atau dasar pemberian materi dari mana kita bisa memulai pelatihan.
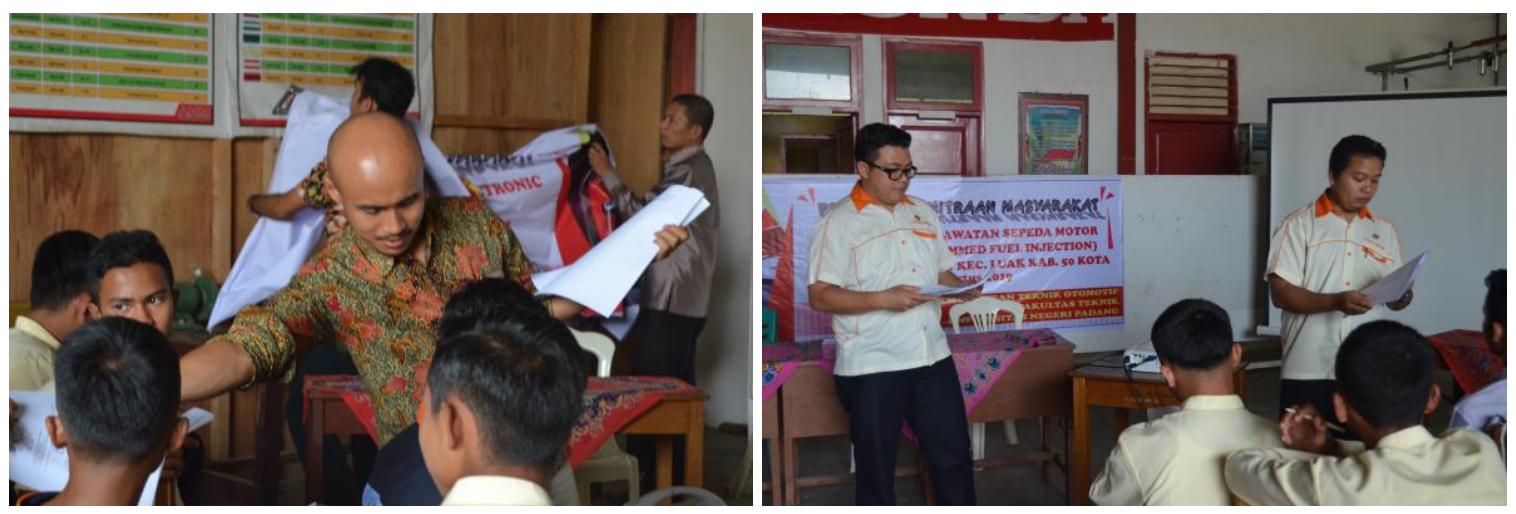

Gambar 3. Proses pelaksanaan pretest

Setelah dilakukan pretes maka dilajutkan kegiatan teori yang disampaikan oleh Ahmad Arif S.Pd MT tentang pengenalan dasar sistem bahan bakar injeksi pada sepeda motor dengan teknologi Programed Fuel injection (PGM FI) kegiatan ini berlangsung selama 4 jam pelajaran. Selama kegiatan juga dilakukan diskusi dengan peserta jika ada hal-hal yang kurang dipahami dan diragukan.
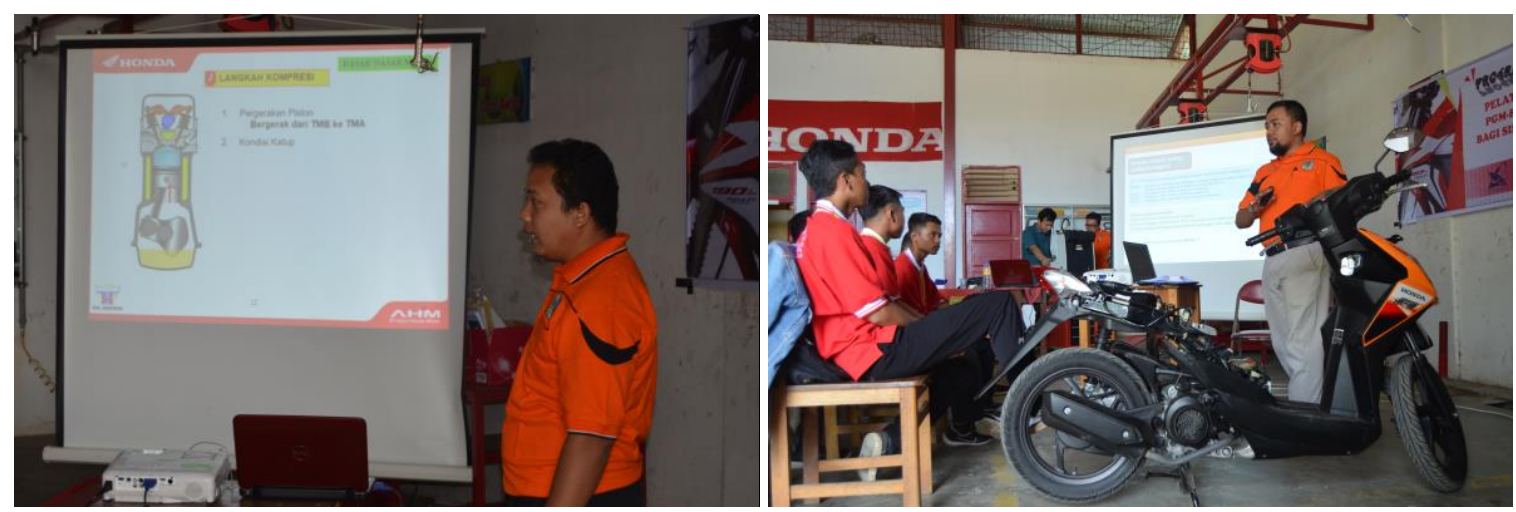

Gambar 4. Penyampaian materi tentang konsep dasar sistem bahan bakar injeksi pada sepeda motor

Selanjutnya berikan materi oleh instruktur Wagino S.Pd, M.Pdt tentang demonstrasi penjelasan cara kerja dari sistem bahan bakar Programed Fuel injection (PGM FI) pada sepeda motor dan simulator materi ini sudah lebih rinci dan memang masuk ke materi pokok pada pelatihan PKM yang dilakukan. Dan dalam materi ini juga sudah mulai diarahkan ke praktek dan mendemontrasikan sistem bahan bakar injeksi pada sepeda motor. 


\section{Suluah Bendang: Jurnal Ilmiah Pengabdian Kepada Masyarakat}
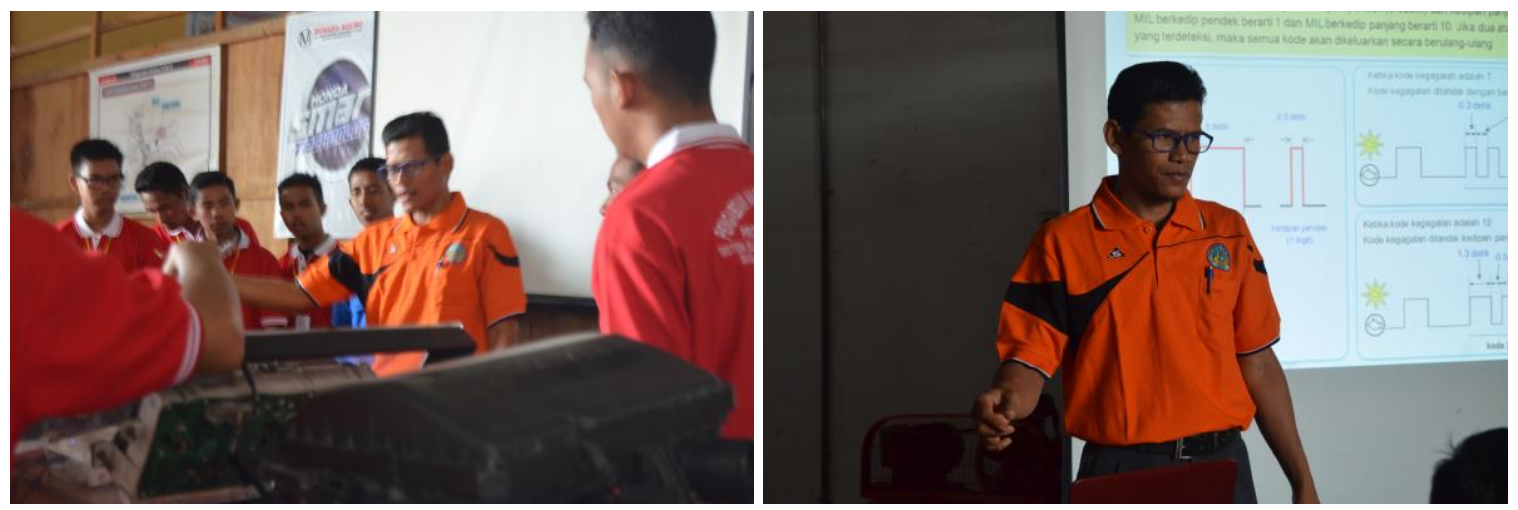

Gambar 5. Penyampaian materi tentang demonstrasi penjelasan cara kerja dari sistem bahan bakar Programed Fuel injection (PGM FI)

Setelah melakukan kegiatan teori maka dilanjutkan dengan kegiatan praktek langsung pada motor dan menggunakan alat yang sudah disiapkan dalam kegiatan ini didampingi oleh instruktur dan tim PKM secara bersama-sama.
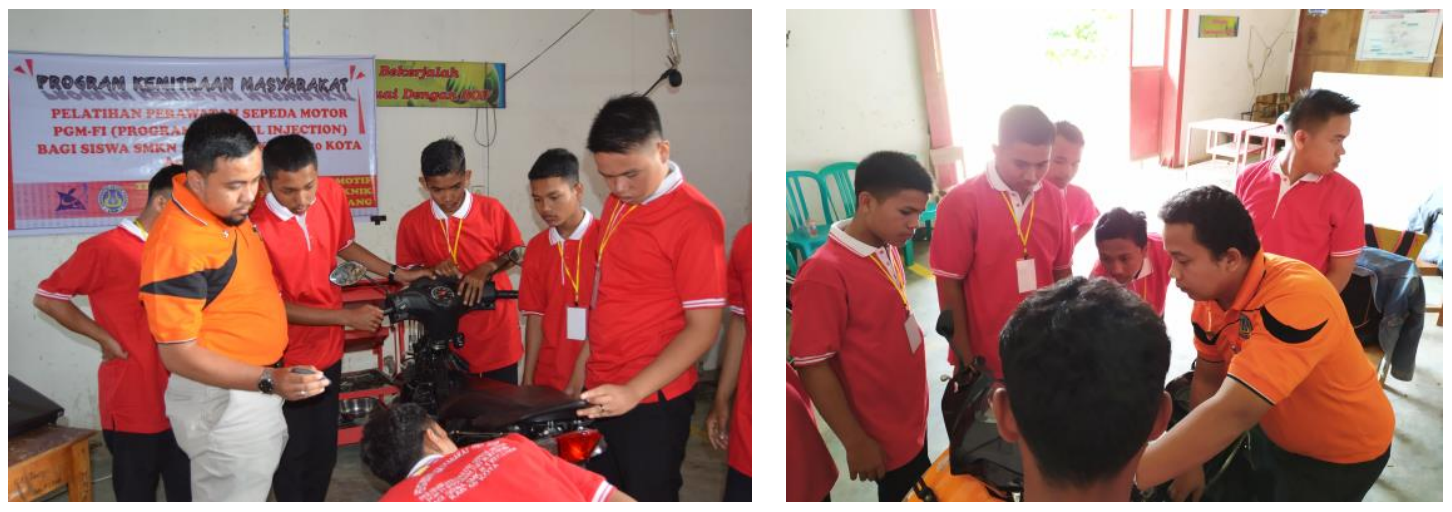

Gambar 6. Kegitan praktek langsung pada sepeda motor

Selama kegiatan berlangsung peserta sangat antusias ini dibuktikan dengan semangat dan keaktifan para peserta. Selama kegitan berlangsung tidak ada kendala yang berarti semua kegiatan berjalan dengan lancar. Awal pengenalan tentang instrumen dalam mendiagnosa kerusakan sistem bahan bakat injeksi yang dengan mengunakan komputer peserta agak kesulitan diawalnya namun setelah diberikan pemahaman dan diulang-ulangi serta mereka melakukan sendiri dan didampingi akhirnya peserta bisa melakukan dengan baik dan benar.

Setelah melakukan kegitan teori dan praktek maka tim PKM kembali melakukan pengukuran kemapuan peserta didik dengan memberikan penilaian (posttest) dengan jumlah soal 25 butir soal objektif dan 5 soal essay. Hasil dari penilaian terhadap peserta dapat dilihat pada grafik dibawah ini. 


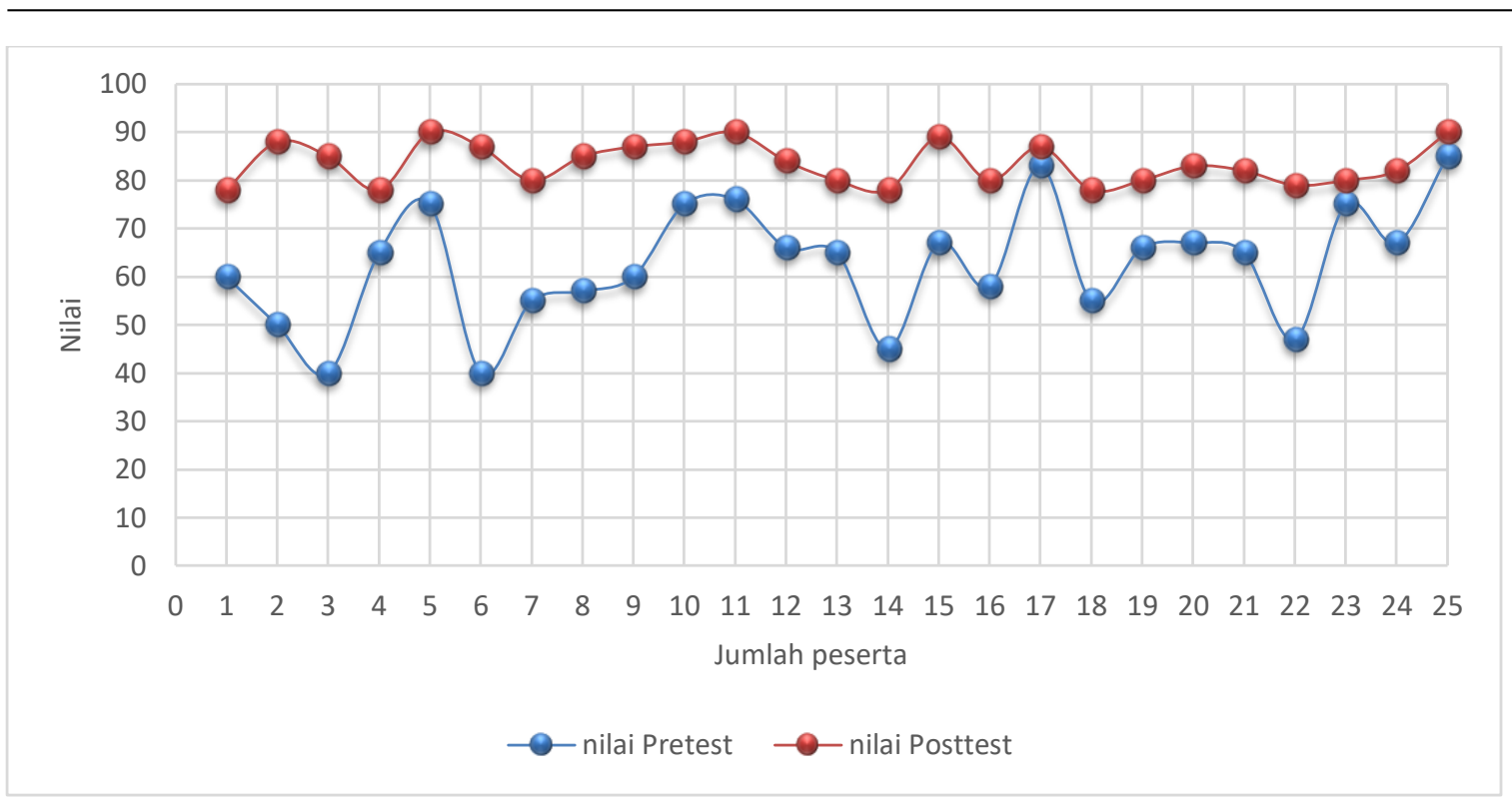

Gambar 7. Grafik nilai pretest dan posttest

Dari grafik diatas dapat dilihat nilai prestest kebanyakan dibawah 80 dan dengan olahan data didapat rata-rata 62,56. Setelah diberikan pelatihan selama 30 jam atau 4 hari maka didapat nilai posttest kebanyakan diatas 80 dengan rata-rata kelas 83,32. Dari data ini kita dapat melihat dengan adanya pelatihan ini dapat meningkatkan pemahaman dan kemampuan siswa dalam mengenal dan memahami prinsip kerja sistem bahan bakar injeksi pada sepeda motor dengan tipe Programed Fuel injection (PGM FI). Pemahaman ini juga sejalan dengan keterampilan yang dimiliki siswa tersebut. Dengan kegiatan tim PKM merasa senang dan bangga bahwa kegiatan ini membawa dampak positif baik bagi institusi Universitas Negeri Padang maupun pihak SMKN 1 Luak. Diakhir kegiatan ini ditutup oleh Kepala sekolah SMKN 1 Luak dengan foto bersama dan penyerahan kenang-kenangan.
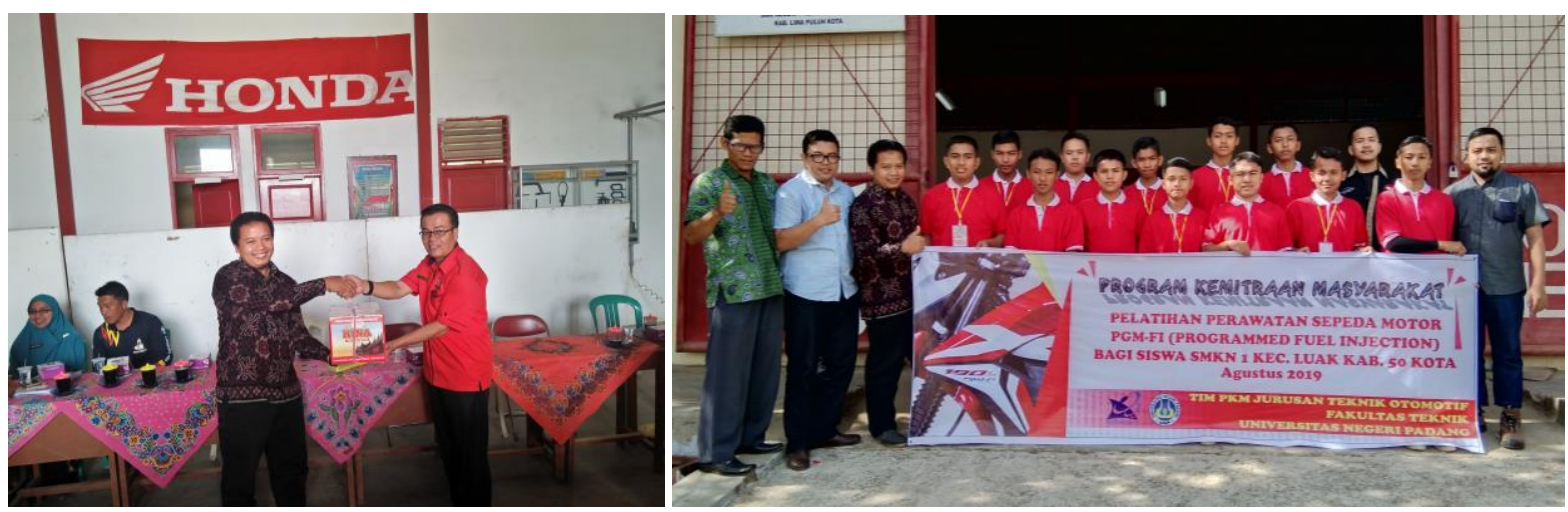

Gambar 8. Foto bersama tim PKM dengan jajaran SMKN 1 Luak

\section{KESIMPULAN}

Setelah melaksanakan kegiatan PKM ini kemampuan siswa dalam pemahaman sistem bahan bakar injeksi tipe Programed Fuel injection (PGM FI) sudah meningkat dan siswa juga bisa meraawat serta menyelesaikan permasalah pada sistem tersebut. Kedepannya diharapkan pihak sekolah melengkapi sarana yang berhubungan dengan sistem injeksi bahan bakar terutama pada sepeda motor sehingga siswa lebih mudah dalam pembelajaran. Dan tim PKM siap untuk diskusi dan membimbing jarak jauh dalam pembelajaran sistem bahan bakar injeksi pada sepeda motor. 
Suluah Bendang: Jurnal Ilmiah Pengabdian Kepada Masyarakat

Vol.19, No.3, 2019

Nuzul Hidayat 1, M. Yasep Setiawan 2, Ahmad Arif 3, dkk

\section{DAFTAR PUSTAKA}

Badan Pusat Statistik Indonesia. (2013). Indonesia Population Projection 2010-2035. Badan Pusat Statistik Indonesia. https://doi.org/2101018

DPR RI. (2003). Undang-Undang No 20 Tahun 2003 tentang Sistem pendidikan nasional. Jakarta: Direktorat Pendidikan Menengah Umum. Retrieved from http://stpibinainsanmulia.ac.id/wp-content/uploads/2013/04/Lamp_2_UU20-2003-Sisdiknas.doc

Hidayat, N., Arif, A., Setiawan, M. Y., \& Afnison, W. (2018). Peningkatan Pengetahuan dan Keterampilan Pemuda Putus Sekolah Melalui Pelatihan Perawatan Berkala Sepeda Motor, 18(2), 83-90.

Pah, N. D., Yudiarso, A., Tjahjono, H., Febriyanto, G. A., Wibisono, E., Prayitno, A., ... Yulardi, A. (2019). Rencana Strategis, 2019.

Pendidikan, N. D. (2007). Materi Sosialisasi dan Pelatihan Kurikulum Tingkat Satuan Pendidikan (KTSP), (4789), 3-5. https://doi.org/10.1248/cpb.37.3229

UU NO.32 TAHUN 2004. (2017). Presiden Republik Indonesia. UU Ri, 3(1), 1-53. 